\title{
Localization of Activity in the Brain
}

$I^{N}$ $\mathrm{N}$ his Ferrier Lecture to the Royal Society, Prof. E. D. Adrian (Proc. Roy. Soc., B, 126, 433 ; 1939) traces the development of the electro-physiological methods of investigation and analysis of the activities of the cerebral cortex from the discovery of the electrical excitability of the brain by Fritsch and Hitzig in 1870. This discovery led to Ferrier's classical work on cerebral localization, the main facts of which have never been seriously questioned, and, indirectly, to the modern method of study of cerebral function, the recording and analysis of the waves of electrical potential, which are the inevitable accompaniment of cortical activity.

Berger's observation that the electrical activity of the cortex could be detected through the unopened skull came at a time when the range of electrical technique was increasing enormously, and the result has been a great and sudden increase in the volume of work published on the subject. The great beauty of the method is that it allows a study of the activity of the whole cortex, and not merely in "the arrival and departure platforms"; but it has the inevitable difficulty of the interpretation of the records from an organ which, by its very nature, never responds twice in precisely the same way. Thus, the local electrical response, which has been shown to follow the arrival of sensory impulses, is related in size, not to the stimulus, but to the previous history of the cortical area on which it falls. In fact, the mechanism of the various types of facilitation which are in constant evidence in the cortex is one of the most fascinating problems.

Some details of the spread of activity in the cortex can be studied in the response of the sleeping, or narcotized, brain to the arrival of a sensory message, but a simpler, because more easily controlled, method is the investigation of the response of the cortex to a direct electrical stimulus. Such a stimulus evokes a reaction locally, not unlike that in response to a sensory message. In the surrounding areas it has two distinct effects : the direct spread of the excited state and a diffuse general increase in excitability, which reveals itself, after repeated stimulation, in the wide spreading of waves of considerable electrical potential, very like those which occur in man during epileptiform convulsions.

It is evident that the cerebral cortex responds readily to sensory messages, and it is therefore difficult to define what is meant by the 'spontaneous' activity of the brain. It seems clear, however, that although the response is to some degree controlled by the character and size of the message reaching it, the final pattern of the cortical activity is determined by the structure of the particular region and by its history. However hopeless may seem the task of analysing the activity of the human brain, these new methods offer some hope, at least, of understanding the mechanisms which exist in it, and from which its behaviour is eventually synthesized.

\section{The Spens Report and General Science}

\section{Discussion by the Association of Women Science Teachers}

$\mathrm{T}$ HE Association of Women Science Teachers held an extraordinary general meeting on March 4 at St. Paul's Girls' School, by kind permission of the Governors and the High Mistress, to consider : (1) the Spens Report in its relation to science in the curriculum; and (2) the Report on General Science, Part 2, recently published by the Science Masters' Association.

The Spens Report sees the value of "the natural sciences when vitally taught" and it emphasizes the need for general interest, but it indicates that this might require less time than a formal study. The idea that the wider study of science might require less time was questioned by the meeting, but members were in agreement that there is still room for pruning and taking stock of the topics which are included, so that the science teaching might instil the desire "to search for truth, goodness and beauty" and give some understanding of the part played in the modern world by the forces of science. Some felt that the emphasis on English subjects as the core of the curriculum might subordinate science, but all were agreed that all subjects had an important part to play in the teaching of English.

There was considerable variation in opinion as to the time which should be allowed to science, but it was felt that the time suggested by the Spens Report is adequate for a general view, but where greater detail and depth of knowledge are desired, more time is necessary. There are, however, the 'pool periods' for which science specialists can make a claim. There was general agreement that specialization at an early age is not desirable. It was felt by many that the school child of to-day is over-taught, and that there is a definite need for leisure in school time so that there might be an opportunity for reading; for this to be of real value the school must possess a good library.

The Spens Report also emphasizes the need for good demonstrations as against excessive practical work on the part of the pupil. There was general agreement that, to produce such demonstrations, both time and good laboratory assistants are essential ; it was also felt that demonstrations might be overdone at the expense of the pupil, who obtains satisfaction from the activity involved in practical work. Care is required to keep the balance between demonstration and individual work by the pupils.

The general feeling of the meeting on the Spens Report can be summed up in the words of a member, who said: "Here we have the core of something which is going to give the mass of our child population 
something that will stay by them", and for this "we have to sacrifice things we think valuable". Surely the end which is desired makes this worth while.

In the discussion on general science which followed, the question of the teaching of general science by one mistress and as one subject, and not by individual specialists, was raised. Some members felt that in the two years preceding School Certificate the syllabus should be taught by specialists in the individual branches. The majority of the members present appeared to consider that more was gained when it is taught by one, and that freshness of outlook, saving of time and greater correlation between the branches might result.

Miss Casswell, headmistress of the Edgbaston High School for Girls, gave an interesting report on the minimum syllabus for general science, which is based on the minimum syllabus of the Association of Assistant Mistresses and of the Association of Women Science Teachers, and on the extended syllabus which is based on the Science Masters' Association's Report on General Science, Part 2. Both of these new syllabuses have been drawn up by the Joint Matriculation Board of the Northern Universities. The minimum syllabus does not have a bias in any particular direction, and it tries to get a unity of science through a study of forms of energy, the material environment and the plants and animals of the environment. The syllabus is such that in ordinary circumstances there should be time for revision and for the introduction of other material which will give the individual teachers freedom of choice. The second paper naturally requires more time, and there would necessarily be opportunity for greater selection and deeper study of sections of the syllabus in which there might be greater interest, and this would involve effort to suit the work to the special circumstances and environment of the school.

Throughout the meeting it could be seen that there was a real and deep appreciation by science teachers of the need to make the teaching such that "it should reveal the influence of scientific thought and achievement in the evolution of our present-day civilisation, and that it should indicate its possibilities, for good and evil, in the future of the human race".

\section{Petroleum and World Politics}

\begin{abstract}
THE importance of the geographical distribution of the heavy minerals around the North and South Atlantic Oceans was stressed in Nature of January 28, p. 169 . It is well to remember, however, that the world distribution of petroleum is also closely related both to the arts of peace and to the horrors of modern warfare. In the present temper of the world, any non-belligerent nation which possesses reserves of petroleum is in danger of finding itself involved in serious political complications. This is especially true of those States of South America which are believed to possess the world's largest reserves of petroleum. In this connexion, some remarks of Dr. D. Rey Vercesi and Dr. Juan H. Caorsi of Montevideo, in a paper of recent date $^{1}$, seem worthy of wider attention.

The authors observe that it is the policy of the more advanced nations of the world to exploit for their own prineipal benefit the supplies of petroleum in the less-advanced countries of South America. Since 1936 , also, it has become the policy of the United States, which is the largest producer as well as the largest consumer of petroleum, to conserve its own resources, which are calculated to be sufficient for about thirty years at the present rate of consumption, and to import large quantities of crude oil from foreign, mainly South American, sources. This attitude of the greater Powers is causing much searching of heart among South American peoples, who see their national resources being rapidly depleted and perhaps to some extent wasted elsewhere in the frantic rush of the modern world. Such stirrings of national spirit help to explain the recent happenings in Mexico and other States.

The authors place the world production of crude oil in 1937 at about two thousand million barrels, and give the following figures of production in the principal producing countries in thousands of barrels (each barrel $=42$ gall.)
\end{abstract}

$\begin{array}{lrrllll}\text { U.S.A. .. } & \ldots & 1,278,000 & \text { Mexico } & \ldots & \ldots & \mathbf{4 6 , 7 0 0} \\ \text { U.S.S.R. } & \ldots & 200,000 & \text { Iraq } & . & \ldots & \mathbf{3 0 , 7 0 0} \\ \text { Venezuela } & \ldots & 185,300 & \text { Colombia } & & \ldots & 20,200 \\ \text { Iran } & \ldots & 78,100 & \text { Peru } & . . & \ldots & \mathbf{1 7 , 7 0 0} \\ \text { Dutch Indies } & \ldots & \mathbf{5 4 , 9 0 0} & \text { Trinidad } & . & \ldots & \mathbf{1 5 , 6 0 0} \\ \text { Rumania } & \ldots & \mathbf{5 2 , 0 0 0} & \text { Argentine } & & \ldots & \mathbf{1 5 , 3 0 0}\end{array}$

They quote General Serrigny's recent estimate in round figures of exportation in tons from the four principal geographical producing regions :

$$
\begin{aligned}
& \begin{array}{llll}
\text { North America } & \ldots & \ldots & 21,000,000 \\
\text { South America } & . & \text {. } & 28,000,000 \\
\text { East Mediterranean } & & \text {. } & 12,000,000
\end{array} \\
& \begin{array}{lll}
\text { East Mediterranean } & \ldots & 12,000,000 \\
\text { Orient } & \text {.. } & 14,000,000
\end{array} \\
& \text { Total _. } \overline{75,000,000}
\end{aligned}
$$

Of this total, about 33 million tons go to Europe.

The authors remark that since the necessities of a European war in which the United States might be involved would greatly increase the demand for petroleum and the non-belligerent countries would not diminish their consumption, it would be necessary to increase world production perhaps two or three times, and supposing that supplies from North America, the east Mediterranean and the Orient were for various reasons unobtainable or unreliable, on South America would fall from necessity or choice the principal charge of meeting the increased demand. The South American States, and especially Venezuela and Colombia, would thus be required to supply the demands of the belligerents.

It is clear that an international situation of great gravity might easily arise, and it is good to know that the younger and clearer minds in South America are already at work upon the problem. The authors urge the necessity of co-operation between the South American States themselves and collaboration in a spirit of peace and good will with the industrialized nations of the world for the general good of humanity. J. D. Falconer.

1 "Politica del Petroleo a seguirse por los paises sudamericanos". A.N.C.A.P., Montevideo, 1938. 